\title{
FEATURES AND MAIN COHERENCES OF THE YOUNG PEOPLES'HELATH CONDITIONS
}

\section{A FIATALOK EGÉSZSÉGI ÁLLAPOTÁNAK JELLEMZŐI ÉS FŐBB ÖSSZEFÜGGÉSEI}

\author{
Tamás Molnár \\ Kaposvári Egyetem, Gazdaságtudományi Kar, Számvitel- és Statisztika tanszék \\ Address: $\quad$ Zolnierska 7400, Kaposvár, Guba Sándor u. 40. \\ Tel.: $\quad+3682505-800 / 283$ \\ E-mail: molnar.tamas@ke.hu
}

\section{Balázs Ferenc Ilk}

Közgazdász-gazdálkodási szakos hallgató

Kaposvári Egyetem, Gazdaságtudományi Kar

Address: $\quad$ 7400, Kaposvár, Guba Sándor u. 40.

Telefon: $\quad+3630 / 552-14-32$

E-mail: $\quad$ ilk.balazs@gmail.com 


\title{
FEATURES AND MAIN COHERENCES OF THE YOUNG PEOPLES'HELATH CONDITIONS*
}

\section{A FIATALOK EGÉSZSÉGI ÁLLAPOTÁNAK JELLEMZŐI ÉS FŐBB ÖSSZEFÜGGÉSEI*}

\author{
Keywords: \\ youth, health, nutrition, alcohol consumption, smoking
}

\begin{abstract}
:
The Hungarian society's hygienic indicators lag behind compared to countries with similar development. This phenomenon is typical of the young age group. Based on the results of the questionnaire survey between the judgement of the dietary habits and the lifestyle strong connection can be manifested. The young persons move exceptionally little and irregularly. Very many young persons smoke and many people from among them smokes strongly. The alcohol consumption is a dominant phenomenon. The smoking and the alcohol consumption are typical of many young persons, these effects cause much damage fixing each other. The more capital reasons of the harmful conduct onto more factors can be leaded back.
\end{abstract}

\section{Kulcsszavak:}

fiatalság, egészségi állapot, táplálkozás, alkohol fogyasztás, dohányzás

\begin{abstract}
Absztrakt:
A magyar társadalom egészségügyi mutatói a környező - azonos fejlettségü - országokéhoz képest elmaradnak. Ez a jelenség a fiatal korosztályra is jellemző. A kérdőíves felmérés eredményei alapján a táplálkozási szokások és az életmód megítélése között szoros kapcsolat mutatható ki. A fiatalok rendkívül keveset és rendszertelenül mozognak. A dohányzási szokásokat tekintve nagyon sok fiatal dohányzik és magas az erösen dohányzók aránya. Az alkoholfogyasztás is domináns jelenség. A dohányzás és az alkoholfogyasztás egyidejüleg szintén sok fiatalra jellemző, amely hatások egymást felerősítve sok kárt okoznak. A káros életvitel főbb okai több tényezőre vezethetőek vissza.
\end{abstract}




\section{BEVEZETÉS}

A statisztikai mutatók fontos tényezői a társadalmi haladás útját kijelölő és értékelő, valamint a piacmüködést értékelő és meghatározó irányelveknek. Szerepük jelentősen megnőtt az utóbbi évtizedekben, az egyre növekvő tájékoztatás iránti igény következményeként, a statisztikák is egyre újabb területeket fognak át. A leggyakrabban arra vonatkozólag vonnak le következtetéseket, hogy melyek a jó irányelvek abból, hogy a gazdasági növekedést előmozdítja-e egy társadalom egészségének megfelelő állapota. Azonban ha a mérési módszerek tévesek, akkor az ezek alapján megjelenő eredmények is azok lehetnek. Ugyanakkor nagy eltérések lehetnek a jelentős társadalmi-gazdasági jelenségek, mint az infláció, munkanélküliség stb. standard mérőszámai és ezek nagyközönség általi érzékelése között. Egyes országokban (pl. Franciaországban vagy az Egyesült Királyságban) ez a különbség bizalmatlanságot szült a hivatalos statisztikák iránt (Stligtz et al, 2008).

Jó ideje aggályok merülnek fel a gazdasági teljesítmény mérőszámaival kapcsolatban, különösen azokkal szemben, amelyek csak a GDP-t veszik figyelembe, illetve amelyek csak ezen alapulnak. Ezek a mérőszámok különösen abból a szempontból kérdésesek, hogy a társadalom jólétének mérőszámaiként nem alkalmazhatóak teljes körüen. A GDP a társadalom jólétének időbeli mérésére, különösen ennek gazdasági, környezeti és szociális dimenziójában, azaz a fenntarthatóságra nem alkalmazható.

Az emberi jólét mérésére a közgazdászok hagyományosan a rendelkezésre álló forrásokra összpontosítanak, melyeket a jövedelem, a vagyon, az áruk vagy a szolgáltatások szerint állapítanak meg. Bár a források fontos tényezők az emberi jólét szempontjából, mégsem bizonyulnak elégségesnek a jólét megállapítására. Az emberi jólét attól függ, hogy a források mire teszik képessé az embereket, és nagy változatosságot mutat az a képesség, hogy az emberek a forrásokat a jólét érdekében használják-e. Mindez azt sugallja, hogy fontos szerepet játszanak azok az indikátorok, amelyek túlmutatnak a jövedelem, a gazdagság és a fogyasztás mutatóin, és magukba foglalják az életminőség pénzben nem kifejezhető oldalait is. Az életminőség az élet azon aspektusaira vonatkozik, amelyek a gazdasági források irányításán túl alakítják az emberi jólétet. (Stligtz et al, 2008).

A globális felmelegedéssel környezeti krízis elé nézünk. A gazdasági teljesítményre vonatkozó olyan mérőszámok, melyek a környezeti problémákkal kapcsolatos kiadásokat is tükröznék, erősen eltérnének a standard mérőszámoktól.

Szintén nagy problémát jelent egyes országokban a túlnépesedés (India, Kína), ahol már drasztikus népességszabályozást is életbe léptettek. Ezzel szemben sok olyan ország is van, 
ahol éppen a népességfogyás (ez főleg a fejlett országokra jellemző) jelent gondot. Az Európai Unió számos országában megfigyelhető ez a sajnálatos jelenség, többek között hazánkban is. A Magyarországon kialakult helyzet nagyon aggasztó, és ha folytatódik az eddigi tendencia, akkor hivatalos források szerint a következö évben már tízmillió alá fog csökkenni a magyar népesség.

További globális, illetve globalizálódó problémákat sem mér egyértelmúen a GDP. Sok országban például az éhezés jelenti a fő gondot, naponta százezrek halnak meg az éhezés következményeként, és az utóbbi időben hazánkban is, egyre több gyermek marad éhen nap, mint nap. Ez olyan méreteket öltött, hogy a közelmúltban egy mozgalom is elindult „,minden gyermek lakjon jól” jelszóval. Mindenesetre elgondolkodtató, hogy a XXI. században, ez újra probléma lehet.

Az ivóvízészletek drasztikus csökkenése és minőségének romlása (többek között a túlnépesedés miatt is) egyes szakemberek szerint akkora horderejü gond lesz, hogy egyes népek migrációjához vezethet. Ezt szintén nem méri a GDP, sőt az egyes termelési folyamatokon keresztül éppen hozzáadott érték növelő tényezőként jelenik meg. Gondoljunk csak a tiszai ciánszennyezésre.

A GDP tehát ugyanúgy, ahogy nem méri a gazdaság környezetre gyakorolt hatását, - mint a társadalomban végbemenő, sok esetben káros folyamatokat, - a fenti komoly problémákat is figyelmen kívül hagyja a számítási metodikájából.

Mindezekből következően nyílván sokkal szélesebb körü megfigyelésekre és mérőszámokra is szükség van.

A társadalom egészsége gyakorlatilag meghatározza annak teljesítőképességét, amit szintén nem méri a GDP. A Humán Fejlettségi Index (HDI) ugyan próbálja mérni ezt, de számítása nem kötelező és sok ország éppen ezért nem is számszerűsíti ennek értékét. Az egészség az emberi élet tartamát és minőségét meghatározó alapvető jellemző. Az egészség az élet legalapvetőbb összetevőjének számít, mivel a nélkül a többi összetevő, gyakorlatilag elveszti az értelmét (EC, 2005; OGY 46/2003). Ennek ellenére jóval többet tudunk az egészségügy költségeiről és az ellátott betegek számáról, mint az ellátás hatásairól és általában a lakosság egészségi állapotáról. Az egészség hatással van mind az élet tartamára, mind annak minőségére. Míg az előbbire igen széles körben állnak rendelkezésre adatok, az utóbbi mérésében maradnak még kihívások. Az egészség értékeléséhez szükség van a mortalitás és a morbiditás megfelelő mértékeire.

Nagyon fontos tényező a társadalom egészségi állapota, annak „stock” és „flow” megfigyelése és mérése egyaránt, hiszen az egészségi állapot és az abban végbemenő 
változások alapvetően befolyásolják egy társadalom teljesítőképességét, így a gazdasági fejlettséget is. Ilyen értelemben sokkal fontosabb kategória, mit a gazdaság adott pillanatban mért GDP-je.

A szakemberek álláspontja mára már odáig fejlődött, hogy egyenesen „egészség gazdaságról” beszélnek, sőt egyre hangosabban állnak ki a mellett az álláspont mellett, hogy az egészségügyi ellátórendszert igenis tekintse a mindenkori kormányzat GDP termelőnek és ne GDP fogyasztónak.

Egy társadalom gazdasági és egyéb teljesítőképességének fő letéteményesei a fiatalok, a fiatal felnőttek. Ezért ennek a korosztálynak az egészségi állapota rendkívül jelentős kérdés. Több kutatás, illetve az ezekből megjelent publikáció foglalkozik a fiatalok egészségi állapotával, illetve elemzi a jelenségek okait. A számtalan publikáció és tanulmány, vagy közönséges újságcikk közös nevezője az, hogy a fiatalok egészségi állapota katasztrofálisan rossz. Sokkal több a fizikailag és mentálisan segítségre szoruló fiatal, mint húsz évvel ezelőtt. A jó egészség nem önmagában való érték, a testi és lelki egészségesség a minőségi élet alapja. A népesség nem megfelelő egészségi állapota, valamint a korai halálozás által elvesztett életévek egy ország számára gazdasági veszteséget is jelentenek. A magyar felnőtt lakosság egészségmutatóinak romlása az 1960-as évek végétől vált szembetűnővé és 1993ban érte el a legrosszabb paramétereket, ekkor „tetőzött”. A születéskor várható élettartam hosszú évekig tartó csökkenése után 1996-tól már egy kicsit jobb értéket mutat, de számos országhoz (például a nyugat-európai, skandináv országokhoz és Japánhoz) képest még mindig nagyon alacsony.

A betegségek kialakulásáért elsősorban a környezeti és az életmódbeli károsító tényezők tehetők felelőssé, a megbetegedések okaként főleg a dohányzás, az alkohol és a stressz játszik nagyon jelentős szerepet. A környezet alatt nemcsak a fizikai tényezők (a talaj-, vízés levegőszennyeződés, a zaj és zsúfoltság) értendők, ide tartoznak olyan jelenségek is, mint a „szegénység szintjén élés”, a kirívó társadalmi és vagyoni egyenlőtlenségek.

A túl gyors társadalmi változások, a bizonytalan életkilátások következtében kialakuló feszültség, a lakossági terhek nagymértékü növekedése, (ami a jelenlegi gazdasági válság közepette még markánsabban jelentkezik) sokszor a betegségek igazi okait jelentik. A környezeti fizikai feltételeinek romlásáért mind lokális, mind globális szinten az ember magatartása tehető felelőssé. 


\section{A fiatalok egészségi állapotának néhány általános jellemzője}

Rohamosan növekszik a légszennyezéssel, táplálkozási és egyéb környezeti allergénekkel összefüggést mutató légúti, emésztőszervi és bőrgyógyászati allergiás megbetegedések száma és aránya.

A fiatalok csökkent fizikai teherbíró-képességét jelzik a testtartási rendellenességek (hanyag tartás, lúdtalp, gerincferdülés) és azok az adatok, amelyek az elégtelen fizikai terhelhetőséget (fittség) bizonyítják. Egyre magasabb az elhízott gyermekek aránya. Gyakoriak a mentális és a szorongásos problémák, és egyre elterjedtebb a gyermekkori depresszió jelensége is.

A fiatalok egészségi állapotának romlásában meghatározóak az egyre szaporodó testtartási és mozgásszervi problémák, valamint az elhízás elsősorban az általános életmódváltozás eredménye: gyermekeink kevesebbet mozognak, sokkal többet ülnek a televízió, a videó és a számítógép előtt. Táplálkozási szokásaikra jellemző, hogy emelkedik a nassolók (édesség, üdítőitalok fogyasztása) és gyorséttermi ételeket fogyasztók aránya. Sokan rendszertelenül étkeznek és sajnos nem elhanyagolható azon fiatalok aránya, akik egyszerüen nem engedhetik meg maguknak a rendszeres étkezés „luxusát”.

Az egészségi állapot jellemzésére jól szolgál és széles körben használt az egészség és a közérzet (életérzés) önminősítése. A magyar gyermekek 60-80 százalékról (életkortól és nemtől függően) elmondható, hogy pozitív életérzésű, 80-90 százalékról, hogy egészségesnek tartja magát. Meg kell azonban jegyezni, hogy 1986-1997 között emelkedett a kedvezőtlen életérzésű („,nem boldog” és „,egyáltalán nem boldog”) magyar 11-17 éves diákok aránya.

A gyermek és serdülőkorúak egészségi állapotát jellemző mutatókból ki kell emelnünk a 1019 évesek halálozásának kétharmadáért felelős baleseteket és öngyilkosságokat, valamint a gyermekek ellen elkövetett erőszakos cselekményeket. Évente átlagosan 200-300 gyermek hal meg baleset, 60-100 gyermek öngyilkosság és 20-30 gyermek-bántalmazás és erőszak következtében (Aszmann, 2010). A gyermekek bántalmazása, a gyermekkori öngyilkosságok viszonylag magas száma a társadalmon belüli feszültség növekedését, valamint a szülői kontroll gyengülését jelzik.

\section{CÉLKITÜZÉSEK ÉS MÓDSZEREK}

A tanulmány a fiatalok egészségi állapotát vizsgálta olyan aspektusból is, hogy mi a véleményük saját egészségükröl, illetve annak változásáról. A megkérdezettek zömmel a 18 és 22 év közötti körosztályba tartozó fiatalok voltak (n=265). A kérdőívben a háttérváltozók 
mellett szerepeltek az étkezéssel és a szabadidős tevékenységgel kapcsolatos kérdések is, ezeken kívül rákérdeztünk a káros szokásokra, és a saját véleményükre is az egészséget érintő kérdésekben. Az elemzés egyszerű statisztikai módszerekkel (általában viszonyszámok alkalmazásával) és bonyolultabb metodikákkal (pl. kereszttábla elemzés) is történt. A számításokat Excel és SPSS programcsomagok segítették.

\section{EREDMÉNYEK}

\section{A felmérésben résztvevők jellemzői}

A kiküldött kérdőívet 265-en küldték vissza, 74\%-ban nők és csak 26\%-ban férfi (1. ábra).

\section{1. ábra: A nemek megoszlása a kitöltött kérdőívek esetében}

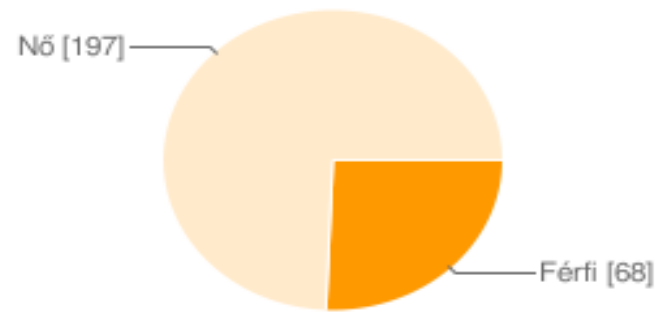

Forrás: A szerzők saját számítása

A kérdőívet kitöltők ötöde fővárosi, 152 városban lakó fiatal vett részt a felmérésben (ebből megyeszékhelyen lakik 78 fö, azaz 51\%), míg a kisebb településekröl összesen 62-en töltötték ki az ürlapot (2. ábra).

\section{2. ábra: A felmérésben résztvevők lakóhely szerinti megoszlása}

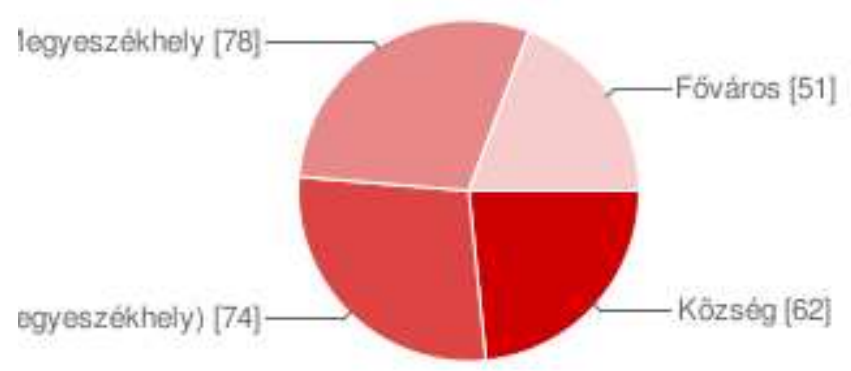

Forrás: A szerzők saját számítása 
A megyéket tekintve Győr-Moson -Sopron, Hajdú-Bihar, Pest és Somogy megyéből érkezett vissza a legtöbb kitöltött kérdőív. Megemlíthető még Veszprém megye, viszont a többi megyéből nem, vagy csak nagyon kevés kérdőív érkezett vissza.

A megkérdezett fiatalok nagy részének családjában alacsony egy főre jutó jövedelmek jellemzőek: a kérdőíven szereplő 6 jövedelemcsoportból a felmérésben részt vevők közül mintegy $80 \%$ arányban jelölték az első három kategória valamelyikét, ami azt jelenti, hogy ezekben a családokban 100 ezer Ft alatt van az egy före jutó jövedelem. A felső három kategóriában elhelyezkedő válaszoló közül csak 3\% esetén magasabb az egy főre jutó jövedelem, mint 150 ezer Ft.

\section{A fiatalok táplálkozási szokásai}

Az egészségi állapot egyik alapvető meghatározó faktora a táplálkozás. A felmérésben résztvevő fiatalok erre vonatkozólag részletesen kifejthették véleményüket, hiszen a kérdőív tág kereteket adott erre. A megkérdezettek közel 9\%-a tartja úgy önmagáról, hogy teljes mértékben egészségesen táplálkozik, közülük a fő étkezéseket szinte mindegyikük előnyben részesíti és be is tartja. Elgondolkodtató, hogy a lányok aránya ebben a csoportban több mint kétszer akkora, mint fiútársaiké. Ugyanakkor a felmérésben szereplő fiatalok esetén az egészséges életmódra való törekevés, illetve ennek megítélése és a nemek között nem mutatható ki összefüggés. A Cramer-féle „V” csak 0,055, ráadásul a kereszttáblából számolt Pearson-féle kontingencia együttható értéke nem is volt szignifikáns $(\alpha \geq 5 \%)$. Az általánosnak mondható nézet, miszerint a nők egészségesebben élnek, illetve igyekeznek egészségesebben élni, mint a férfiak ebben az esetben nem volt statisztikailag igazolható.

Nagyon lényeges kérdés, hogy egy adott populáció milyen egészségesen étkezik, hiszen a táplálék minősége, mennyisége és a táplálkozás módja nagymértékben befolyásolja az egészséget. A kérdőív ezek vizsgálatára is lehetőséget adott.

A megkérdezettek válaszaiból kiderült, hogy a táplálkozás és az életmód megítélése szorosan összefügg egymással. Ugyanis az előbb említett két változó kimenetei (mindegyiken belül a „helyes” és „,helytelen” kategóriákat figyelembe véve) között elvégzett kereszttábla elemzés nagyon szoros összefüggést mutatott. A Cramer-féle „V” értéke nagyon szoros, 0,9 feletti kategóriában található (,V”=0,939); és itt ráadásul szignifikánsnak is mondható $(\alpha \leq 0,1 \%)$. Tehát, aki helyesen táplálkozik, az úgy tartja magáról, hogy egészséges életvitelt is folytat. Ez a megfigyelés fordítva is igaz, azok a válaszadók, akik 
saját maguk szerint helytelenül táplálkoznak, zömmel azt a választ jelölték meg, hogy az életmódjuk kívánnivalót hagy maga után.

A saját maguk szerint legegészségesebben élők inkább az ásványvizeket részesítik előnyben, mint a szénsavas üdítőket és nem „,élnek” energiaitalokkal. Ők azok, akik ritkán vagy egyáltalán nem isznak kávét, viszont a teát szívesen elfogyasztják. Közülük csak nagyon kevesen isznak szeszes italt, és amikor ez elöfordul akkor is csak nagyon ritkán és nagyon kevés alkoholt (sör, bor, égetett szeszes ital) fogyasztanak.

A húsféleségek tekintetében inkább a sertés és a szárnyas húsokat kedvelik, ritkábban esznek marha-, valamint halhúst. Előnyben részesítik a zöldségeket és a gyümölcsöket. A tejtermékek közül inkább csak a tej fogyasztása a jellemző, a többi tejterméké nem, még a sajté sem. Sokat sportolnak, vitaminokat szednek, egyáltalán nem dohányoznak, és nem szorulnak semmiféle gyógyszer szedésére sem. Akik úgy tartják, hogy egészségesen élnek, azok között ritkán vagy egyáltalán nem jellemző a stressz, és tudatosan próbálják is azt elkerülni. Az önmegítélés alapján egészségtelen életmódot folytató fiatalok csoportjába tartozók étkezési szokásai nem sokkal különböznek a többi megkérdezett táplálkozásától. Általában betartják a fó étkezéseket és nem vetik meg az ásványvizet és a teát, valamint a tejet- és a tejtermékeket is előszeretettel fogyasztják. Ez utóbbiak közül a sajtfélék kiemelkedő szerepet játszanak, étkezéseikben gyakoriak a zöldségfélék és a gyümölcsök is. Tehát az étkezéseikben nem különböznek döntően a megkérdezettek átlagától, ebből az következik, hogy nem a saját táplálkozásuk miatt gondolják úgy, hogy egészségtelenül élnek, hanem a következőkben kifejtendő mozgásszegény életmód miatt.

\section{A fiatalok szabadidő-eltöltése}

Az egészséges életmód megítélés szempontjából fontos szerep jut a szabadidős tevékenységeknek ezeken belül is kiemelkedően a sportnak. Ebben a tekintetben az önmagukat egészségtelen életmóddal titulált csoportnak már jelentősen különböznek a szokásai az egészséges életmódot folytatóktól. Nagyon kevés a rendszeresen sportolók száma és viszonylag sokan vannak, akik egyáltalán nem mozognak. Közülük sokan dohányoznak és gyakori ebben a csoportban az alkoholfogyasztás is.

A rendszeresen mozgó fiatalok zöme minimum egy órát tölt alkalmanként sportolással. Ennek az „ellenkezője” is igaz, nevezetesen a nagyon ritkán, vagy egyáltalán nem „sportolók” egy-egy alkalommal csak nagyon keveset töltenek mozgással.

Egy korábbi felmérés szerint a magyar fiatalok egyharmadáról valószínüsíthető, hogy eleget sportol, a másik egyharmad aktivitása éppen elfogadható, a maradék egyharmad pedig alig, 
vagy semmit sem sportol. A rendszeresen sportolók aránya összességében emelkedett, viszont nemzetközi összehasonlításban a fizikailag aktív magyar fiatalok aránya alacsony. Folyamatosan növekszik azoknak a tanulóknak az aránya, akik naponta hosszú időt töltenek el televízió és videó nézéssel, és sokan töltik el szabadidejüket szervezetlenül és tervezetlenül, sőt közülük sokan csavarognak. (Aszmann, 2010. p. 5)

A jelen felmérésben részt vevő fiatalok közel 15\%-a egyáltalán nem mozog, további egyharmada alkalmanként nem sportol többet 30 percnél, ami nagyon kevés idő. A megkérdezettek egyharmada mozog csak rendszeresen, ami azt jelenti, hogy mindennap, de legalább hetente többször folytat aktív sporttevékenységet. Ezek a fiatalok alkalmanként legalább egy órát töltenek intenzív sportolással, többen pedig egy edzés alkalmával másfél óránál is többet mozognak. Közülük csak nagyon kevesen szednek valamilyen gyógyszert vagy étrend kiegészítőt, a vitaminokon kívül. Érdekes, hogy ők úgy tesznek az egészségükért, hogy a sporttevékenység mellett tudatosan kerülik a stresszhelyzeteket.

\section{A felmérésben részt vevők dohányzási szokásai}

A gyermekkorúak között világszerte egyre korábbi életkorban jelentkeznek az egészséget károsító szokások, amelyek nemcsak a későbbi, a felnőttkori, de a jelen egészségi állapotukat is befolyásolják (Tokada et al. 1994). A rendszeresen dohányzók gyakrabban szenvednek légúti betegségekben és a dohányzás asztmás rohamot kiváltó, illetve súlyosbító szerepe is megfigyelhetö (Cook GD, Strachan DP, 1997; Lange et al., 1998; Nuorti et al. 2000). E mellett nem elhanyagolható az a tény sem, hogy a káros szokásuk mintegy melléktermékeként a körülöttük élö, és egészségtudatos magatartást követni kívánó ismerősök, rokonok, barátok, vagy éppen teljesen ismeretlenek egészségét károsítják a passzív dohányzás okozta ártalmakkal (Vupputuri et al. 1999). Egyes vélemények szerint a dohányosok még saját magukat is kiteszik a passzív dohányzás okozta rizikófaktoroknak az aktív dohányzás okozta kártételek mellett. Tulajdonképpen „duplán” mérgezik magukat.

Az Országos Lakossági Egészség Felmérés 2000 kutatási jelentése szerint a 18 év feletti magyar férfiak 40,7\%-a, a nők 26,3\%-a dohányzik (rendszeresen vagy alkalomszerüen). Az egy lakosra eső cigarettafogyasztás 1999-ben 2400 szál/fő volt, míg az Európai Unió országaiban átlagosan 1600 szál/fő. A Fact Intézet 1999-es felmérése szerint a magyar lakosság 65\%-a szenved a passzív dohányzás ártalmaitól, átlagosan napi 270 percet töltve olyan légtérben, ahol mások dohányfüstjét szívja. A Központi Statisztikai Hivatal 2002 elején közzétett adatai szerint Magyarországon ma évente 28 ezer ember halála írható egyedül a dohányzás rovására. Ez körülbelül kétszer több mint ahányan alkoholizmus, 
kábítószer-fogyasztás, baleset, eröszakos halál, öngyilkosság és AIDS miatt összesen meghalnak. A magyar férfiak tüdőrák-halandósága a világon a legmagasabb. A 28 ezres halálozási adat már csak azért is megdöbbentő, mert a magyar lakosság évente körülbelül 18-20 ezer fővel csökken. Ebből következően, ha csak a dohányzás okozta káros hatásokat kiküszöbölnénk, akkor növekedne a honi népesség!

A dohányzás káros hatásait számtalan publikáció ecseteli, jelen tanulmányban nem az elsődleges cél, hogy ezt bővebben kifejtsük. Azonban azt mindenképpen meg kell említeni, hogy az enyhébb hurutos megbetegedéseken túl, a halálos daganatos és főleg a tüdőrákos kórokok vezető oka a dohányzás. A végzetes végső diagnózis előtti stádiumok ugyanúgy rontják az életminőséget és a szervezet sok egyéb betegséggel szembeni védekezőképessége jelentősen csökken. Ez pedig oda vezet, hogy a szervezet teljesítőképessége néhol jelentős mértékben csökken. Ebből az következik, hogy a társadalom teljesítőképessége csökkenni fog, hiszen több ember, többször és hosszabb időre megy táppénzre, jelentősen megnőnek a gyógyítási, illetve a betegápolási költségek.

A magyar tanulók egyre fiatalabb életkorban gyújtanak rá, minden korcsoportban emelkedett a dohányzó lányok aránya. „Naponta dohányzik a nyolcadikos fiúk 8 százaléka, a nyolcadikos lányok 3,5 százaléka, a 16-17 éves középiskolás fiúk 21,4, a lányok 16 s az ugyanilyen korú szakmunkástanuló fiúk 41 és a lányok 32 százaléka.”(Aszmann, 2010. p. 7) A jelen felmérésben részt vevő fiatalok esetén az egészséges életmód megítélése és a dohányzási szokások közötti kereszttábla-elemzés kimutatta, hogy a két tényező között egyértelmű a szignifikáns összefüggés $(\alpha \leq 0,1 \%)$, habár a kapcsolat csak gyengének mutatkozik (Cramer-féle „V”= 0,287). Főleg azon fiatalok száma jelent nagyságrendi fölényt a többi csoporttal szemben, akik egészséges életmódot folytatnak, és egyáltalán nem dohányoznak. Ezen diákok az összes megkérdezettek létszámának 55\%-át teszik ki. Sokan vannak, akik naponta rágyújtanak, és nem elhanyagolható azok száma sem, akik hetente, illetve havonta többször dohányoznak. Mindent összevetve csak a megkérdezettek 38\%-a mondta, hogy soha nem gyújtott rá. Ez a tény mindenestre elgondolkodtató. Sajnos már régóta megfigyelhető jelenség, hogy a fiatalok egyre gyakrabban, egyre nagyobb arányban és egyre korábbi életszakaszukban kezdenek el dohányozni.

\section{A fiatalok alkoholfogyasztási szokásai}

Általános jelenség, hogy a fiatalok alkohol fogyasztási szokásai is kedvezőtlenebbé váltak a korábbi időszakokhoz képest: minden vizsgált életkori csoportban emelkedett azoknak a 
fiataloknak az aránya, akik többször kerültek már alkoholos befolyásoltság alá. A lányok alkohol fogyasztási szokásai pedig közelítenek a fiúk szokásaihoz Szembetűnő, hogy a rövidital fogyasztásának gyakorisága sem sokban marad el a fiúkétól (Aszmann, 2010).

Korábbi vizsgálatok egyértelmüen rámutatnak, hogy sok országban, így hazánkban is aggasztó a dohányzó és alkoholt fogyasztó lányok arányának emelkedése. Vannak olyan országok, ahol a lányok ebből a szempontból a fiúknál kedvezőtlenebb képet mutatnak. A napi dohányzás tekintetében 15 éves serdülőink a nemzetközi rangsor élére kerültek. A pszichoaktív szerek valamilyen típusát a serdülők többsége kipróbálja, azonban sokkal kevesebben válnak rendszeres fogyasztóvá. Sajnos az sem új keletű jelenség, hogy a parti drogok elterjedtek főleg a szórakozóhelyeken (pl. discókban, stb.). Alkohollal együtt még erősebben fejtik ki hatásukat ezek a szerek, és nemegyszer halálesettel végződnek az ilyen sajnálatos események.

\section{A dohányzás és az alkoholfogyasztás összefüggése}

Általános tapasztalat, hogy az alkoholfogyasztás egy szórakozóhelyen, vagy egy baráti társaságban generálja a másik rossz szokást, a dohányzást (Sörensen et al. 2000). A megkérdezett fiatalok több mint egyharmada dohányzik rendszeresen és a felmérésben részt vevők csak közel 17 \%-a válaszolta azt, hogy egyáltalán nem dohányzik.

A dohányzás és az alkohol fogyasztás kapcsolatát kereszttábla elemzéssel vizsgáltuk és a két rossz szokás közötti kapcsolat szignifikáns összefüggést mutatott ( $\alpha \leq 0,1 \%)$. A kapcsolat erősségére vonatkozóan viszont csak egy gyenge kapcsolatot találtunk (Cramer-féle „,V”= 0,315). Ennek fó oka az, hogy azoknak a fiataloknak a száma relatíve magas, akik ugyan nem isznak alkoholt, de gyakran dohányoznak. Így a két tulajdonság együttes eloszlását ennek a „cellának” a gyakorisága torzítja, ezért nem jöhetett ki szorosabb kapcsolat a két tényező között.

\section{AZ EREDMÉNYEK ÉRTÉKELÉSE KÖVETKEZTETÉSEK}

\section{A megváltozott életvitel főbb okai}

A rizikótényezők kutatói a gyermek szűkebb és tágabb környezetében megtalálható következő veszélyekre hívták fel a figyelmet: 
- A konfliktusokkal teli, funkciójában már nem müködő családi háttér;

- a szülők deviáns viselkedése és alkoholizmusa;

- a gyermek feletti hiányos kontroll;

- a gyermek szabadidejének szervezetlen felhasználása, a csavargás;

- a kudarcokkal teli iskolai pályafutás.

Kifejezetten hátrányos helyzetü gyermekek között végzett vizsgálatok azonban azt is bizonyították, hogy a hátrányos körülmények ellenére a gyermekek bizonyos hányadára nem jellemező az egészségveszélyeztető életmód. Ezekről a „védett” gyermekekről általában elmondható, hogy ellenállóbban a társas hatásokkal szemben, jövőjüket tekintve tudatosabbak, egészséges önbizalommal rendelkeznek, és a stresszhelyzetekben adaptív megküzdési módszereket használnak.

\section{KÖVETKEZTETÉSEK ÉS AJÁNLÁSOK}

Az egészségmagatartásra vonatkozó elemzéseink - hasonlóan a szakirodalmi adatokhoz igazolják, hogy az életmódbeli szokások csoportosulnak. A dohányzás, alkoholfogyasztás és bizonyos fajta étel és italfogyasztási szokások (kávé, üdítőitalok, gyorséttermi ételek) szignifikáns összefüggést mutatnak egymással és a fiatalok szabadidő-eltöltési szokásaival. A felsorolt szokások együtt járása egy olyan életformára utal, amelyre a rendszeres dohányzás és az alkoholfogyasztás mellett jellemző, hogy a fiatal sok időt (estét) tölt el az otthonán kívül, gyakran céltalanul csavarogva. 


\title{
IRODALOMJEGYZÉK
}

46/2003. (IV.16.) OGY határozat az Egészség Évtizedének Johan Béla Nemzeti Programjáról

Aszmann A: A magyar diákok egészségi állapota és az iskola. Internet, letöltve: 2010. január 10. p. 1-10.

Cook GD, Strachan DP: Parental smoking and prevalence of respiratory symptoms and asthma in school age children. Thorax 1997; 52 p. 1081-1094.

European Commission - Health and Consumer Protection Directorate-General: The contribution of the health to the economy in the European Union. European Communities, 2005.

Lange P, Parner J, Vestbo J, Schnohr P, Jensen G. A 15 year follow-up study of ventilatory function in adults with asthma. New Engl J Med 1998; 339: 1194-1200.

Nuorti JP, Buttler JC, Farley M, Harrison LH, McGeer A, Kolczak MS, Breiman RF. Cigarette smoking and invasive pneumoccal disease. New Engl J Med 2000; 342 p. 681689.

Országos Lakossági Egészség Felmérés (OLEF) 2000.

Sörensen LT, Jörgensen T, Kirkeby LT, Skovdal J, Vennits B, Willie-Jörgensen P. Smoking and alcohol abuse are major risk factors for anastigmatic leakage in colorectal surgery. $\mathrm{Br} \mathrm{J}$ Surg 2000 .

Stiglitz, J.E; Amartya SEN, Fitoussi J.P: Report by the Commission on the Measurement of Economic Performance and Social Progress 2008.

Tokada A, Yokada Y, Urano T. The physiological aspects of smoking. Thrombosis Research 1994; 76 p. 1-31

Vupputuri S, Allen K, Prerost MR, Hughes J, Whelton PK. Passive smoking and the risk of coronary heart disease - a meta-analysis of epidemiological studies. New Engl J Med 1999; 340 p. $920-926$.

\author{
Extended abstract
}

\section{FEATURES AND MAIN COHERENCES OF THE YOUNG PEOPLES'HELATH CONDITIONS*}

\section{A FIATALOK EGÉSZSÉGI ÁLLAPOTÁNAK JELLEMZŐI ÉS FŐBB ÖSSZEFÜGGÉSEI*}

\section{Tamás Molnár}

Cím: Kaposvári Egyetem, Gazdaságtudományi Kar, Számvitel- és Statisztika tanszék

7400, Kaposvár, Guba Sándor u. 40.

Telefon: +36 82 505-800/283

E-mail: molnar.tamas@ke.hu 


\author{
Ilk Balázs Ferenc \\ Közgazdász-gazdálkodási szakos hallgató \\ Cím: Kaposvári Egyetem, Gazdaságtudományi Kar \\ 7400, Kaposvár, Guba Sándor u. 40. \\ Telefon: +3630/552-14-32 \\ E-mail: ilk.balazs@gmail.com
}

The statistical indicators are important indicators to trace out and appraising the governing principles of the social progress. Their role increased in the past decades. The statistics are presenting newer and newer areas, because of the increasing claim for information. Frequently their deducing the conclusion about the society's state of health is promoting or not the economical growth of a country. If the measuring methods are wrong, than the result grounded on these methods could be defective also. At the same time there could be big differences in the standard index-numbers of the significant social-economical symptoms, like the inflation's, unemployment's and their sensation by the general public. In some countries (ex. in France or in the United Kingdom) this difference affected mistrust for the official statistics. (Stiglitz et al, 2008)

For a long time scruples appears in connection with the index-numbers of the economic performance, especially with those, which only based on the GDP or based only on it. These index-numbers are pending - particularly from that viewpoint - that they cannot be applied overall as the index-numbers of the society's prosperity. The GDP is not adaptable for the temporal measurement of the society's prosperity, especially its economic, environmental and social dimension; also it is applicable to measuring the sustainability.

The economists are conventionally focusing on available sources, which they allocating by income, assets, goods or services. They do not prove to be sufficient after all although the sources are important factors from the viewpoint of the human prosperity. The human prosperity depends on how the sources make the peoples capable and the ability whether the peoples using the sources in the interest of the prosperity show big variety. All this suggests that those indicators are playing an important role which shows trough the richness and the consumption, and includes the sides of the quality of life which cannot be expressed in money. The quality of life concerns the aspects of the life, which shape the human prosperity beyond the management of the economic sources. (Stligtz et al, 2008). 
We are standing before an environmental crisis because of the global warming. The indexnumbers concerning the economic performance, which ones including the expenses related with the environmental problems, would differ from the standard index-numbers strongly. Also in some countries (like India or China) the overpopulation means a big problem, where a drastic population regulation brought already in. In opposite of this, there are many countries, where the population decline (this is usually in developed countries) means trouble. In several countries of the European Union such like in our homeland, is this regrettable symptom observable. The evolved situation in Hungary is very worrisome, and if the tendency continues, already in the next year the Hungary's population will fall below ten million, according to official sources then.

The GDP does not measure additional global or globalized problems unambiguously. For example in many countries the starvation means the primary concern, in consequence of the starvation thousands are dying every day, and lately in our homeland, more and more children stays hungry day to day. This reached so high sizes that a movement entered in the recent past with the password "let every child replete". However it is thought-provoking, that in the XXI. century this may be a problem again.

The drastic decrease of the drinking water sources and the decay of its quality (among other things because of the overpopulation) according to some specialists it will be so big trouble, what may lead to single folks' migration. The GDP does not measure this also, indeed the production processes added value appears as an increasing factor. Let us think only the cyanide pollution of the river Tisza.

The GDP does not measure the economies affect on the environment, - than other, in the society occurring, many times harmful procedures, - leaves the previously mentioned serious problems out of its computational methodology.

All of this results, that we need more comprehensively monitoring and index-numbers.

The society's health practically identifies its efficiency that the GDP does not measure also. Human Development Index (HDI) tries to measure this, but its calculation is not obliging and because of this many countries do not concretize the value of this. The health is a fundamental feature which defines the duration of the human life and its quality. The health is the most elementary component of the life what loses its sense without the other components (EC, 2005; OGY 46/2003). Still we know much more about the expenses of the public healthcare and the provided patients' number, than about the effects of the supply and generally from the population's health conditions. The health has effect on the duration of the life, even as on its quality. While for the former one data are available in a wide circle, 
but in the measurement of the latter one challenge are left yet. To the assessment of the health the measures of the mortality and the morbidity needed.

The society's health conditions is a very important factor, both its stock and flow monitoring and measurement, since the health conditions and the changes happening in it fundamentally influence a society's efficiency, like this the economic development. In a sense like this, it is much more important category, than the GDP of the economy measured in a given moment. The specialists' point of view developed so far already by today, that they talking directly about health economy, indeed they stand on that point of view, that the all-time government should consider the hygienic provision system as a GDP producer and not a GDP consumer. The young persons, the young adults are the capital depositories of a society's economic and other efficiency. The health conditions of this age group are exceptionally considerable questions because of this. Many researches and publications concerned from them deals with the young persons' health conditions, analyses the reasons of the phenomena concerned. The innumerable publications' and study's, or vulgar article's common denominator is that the young persons' health conditions are catastrophically bad. A lot more young person needs help physically and mentally, than twenty years before. The good health is not an alone value, the bodily and spiritual wholesomeness is the basis of the qualitative life. The population's inapposite health conditions, and the years lost by the early mortality means also economic loss for a country. The visible decay of the Hungarian adult population's health indicators got conspicuous at the end of the 1960 years and attained the worst parameters in 1993, reached a peak at this year. After the long decrease of the lifetime which can be waited at birth shows a somewhat better value from 1996 shows already, but comparing with several countries (for example the Western European, Scandinavian countries and Japan) is still very low.

For the formation of illnesses are the environmental and the damaging factors of lifestyle factors responsible, as the reason of the sicknesses mainly the smoking, the alcohol and the stress plays a very considerable role. Under the environment should to understood only the physical factors (the soil-, water and air soiling, the noise and congestion), but phonemes like living on the level of the poverty, the glaring social and financial inequalities.

Many times the real reasons of illnesses are too fast social changes, the tenseness taking shape as a result of the vague life views, big increase of the population burdens (what comes forward even more sharply amidst the present economic crisis). For the decay of the environmental physical conditions also on local and global level is behavior of the people responsible. 